Article

\title{
Reactivity and Mechanism of Photo- and Electrocatalytic Hydrogen Evolution by a Diimine Copper(I) Complex
}

\author{
Maria Drosou ${ }^{1}$, Fotios Kamatsos ${ }^{1} \mathbb{1}$, George Ioannidis ${ }^{1}{ }^{\mathbb{D}}$, Athanasios Zarkadoulas ${ }^{1}{ }^{\mathbb{C}}$, \\ Christiana A. Mitsopoulou ${ }^{1, *(\mathbb{D}}$, Constantina Papatriantafyllopoulou ${ }^{2}$ and Demeter Tzeli ${ }^{3,4}$ (D) \\ 1 Inorganic Chemistry Laboratory, Chemistry Department, National and Kapodistrian University of Athens \\ Panepistimiopolis, 15771 Zografou, Greece; mdrosou@chem.uoa.gr (M.D.); fotiskam@chem.uoa.gr (F.K.); \\ gioannid@chem.uoa.gr (G.I.); azarkadoulas@chem.uoa.gr (A.Z.) \\ 2 School of Chemistry, NUI Galway, H91 TK33 Galway, Ireland; constantina.papatriantafyllopo@nuigalway.ie \\ 3 Theoretical and Physical Chemistry Institute, National Hellenic Research Foundation, 48 Vassileos \\ Constantinou, 11635 Athens, Greece; tzeli@chem.uoa.gr \\ 4 Physical Chemistry Laboratory, Chemistry Department, National and Kapodistrian University of Athens, \\ Panepistimiopolis Zografou, 15771 Athens, Greece \\ * Correspondence: cmitsop@chem.uoa.gr
}

Received: 25 October 2020; Accepted: 9 November 2020; Published: 11 November 2020

\begin{abstract}
The tetrahedral copper(I) diimine complex $\left[\mathrm{Cu}(\mathrm{pq})_{2}\right] \mathrm{BF}_{4}$ displays high photocatalytic activity for the $\mathrm{H}_{2}$ evolution reaction with a turnover number of 3564, thus representing the first type of a $\mathrm{Cu}(\mathrm{I})$ quinoxaline complex capable of catalyzing proton reduction. Electrochemical experiments indicate that molecular mechanisms prevail and DFT calculations provide in-depth insight into the catalytic pathway, suggesting that the coordinating nitrogens play crucial roles in proton exchange and hydrogen formation.
\end{abstract}

Keywords: photocatalytic hydrogen evolution; copper diimine; photocatalyst; electrocatalyst; DFT mechanism

\section{Introduction}

Copper catalysts for proton reduction have recently gained special attention in facilitating solar and electrochemical energy storage via the formation of hydrogen fuel. The abundance, price and diverse redox activity of copper have attracted particular interest [1-4] and many copper complexes have been used as photosensitizers $[5,6]$ redox mediators $[7,8]$ and catalysts for $\mathrm{CO}_{2}$ reduction $[9,10]$ and water oxidation [11-13]. Several $\mathrm{Cu}$-based $\mathrm{H}_{2}$ evolution heterogeneous [14-16] electrocatalysts with good performance have been reported, involving $\mathrm{Cu}(0), \mathrm{Cu}_{2} \mathrm{O}$ [17-22], and $\mathrm{Cu} 2 \mathrm{~S}$ [23] materials. However, there are only a few examples of molecular copper catalysts with well-defined, rationally tunable structures and a comprehensive $\mathrm{H}_{2}$ formation mechanism.

Distorted trigonal bipyramidal and square pyramidal $\mathrm{Cu}(\mathrm{II})$ complexes bearing polypyridine chelates, which are supposed to minimize the inherent lability of the $\mathrm{d}^{10} \mathrm{Cu}(\mathrm{I})$ ion, have been extensively explored as proton reduction electrocatalysts and photocatalysts. Their proposed catalytic pathways involve proton coupled electron transfer (PCET) processes leading to a $\mathrm{Cu}$ (II)-hydride that evolves $\mathrm{H}_{2}$ via intramolecular coupling between the hydride and the proton of a pendant pyridine nitrogen [24-27]. Square planar copper corroles can evolve $\mathrm{H}_{2}$ electrocatalytically via an heterolytic pathway, where a $\mathrm{Cu}$ hydride reacts with a solution proton [28], while a $\mathrm{Cu}(\mathrm{II})$ complex bearing a non-innocent thiosemicarbazone ligand exhibits metal-assisted ligand-centered electrocatalytic $\mathrm{H}_{2}$ evolution [29]. Other $\mathrm{Cu}$ (II) molecular catalysts involving tetradendate triazenido [30], Schiff base [31,32], oxamato [33], 
oxamido [34], phenanthroline [35] and imidazole-based [36] ligands have been recently presented. Notably, many of those catalysts decompose under reductive conditions to afford $\mathrm{H}_{2}$ evolving materials, thus part of their activity is attributed to heterogeneous deposits of nanoparticles [19].

Herein, we examined the photocatalytic $\mathrm{H}_{2}$ production behavior of $\left[\mathrm{Cu}^{\mathrm{I}}(\mathrm{pq})_{2}\right]\left(\mathrm{BF}_{4}\right)\left([1] \mathrm{BF}_{4}\right)$, a homoleptic tetrahedral $\mathrm{Cu}(\mathrm{I})$ diimine complex bearing the bidentate 2-pyridin-2-yl-quinoxaline (pq) ligand (Figure 1a). A complex like [1] ${ }^{+}$but carrying two methyl groups on quinoxaline ring, has been previously reported to be an intermediate in $\mathrm{CO}_{2}$ fixation catalysed by molecular $\left[\mathrm{Cu}(\mathrm{pq})_{2}\left(\mathrm{H}_{2} \mathrm{O}\right)\right]\left(\mathrm{ClO}_{4}\right)_{2}$ [9]. Evaluation of the $\mathrm{H}_{2}$ evolution mechanism by electrochemical and density functional theory (DFT) methods indicates that the quinoxaline nitrogen atoms are primarily protonated and subsequent metal centered PCET leads to the formation of a $\mathrm{Cu}$ (II)-hydride, that can evolve $\mathrm{H}_{2}$ via a low energy transition state.

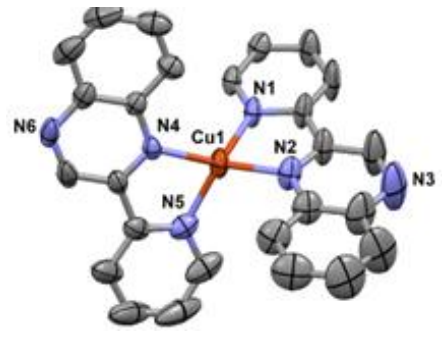

(a)

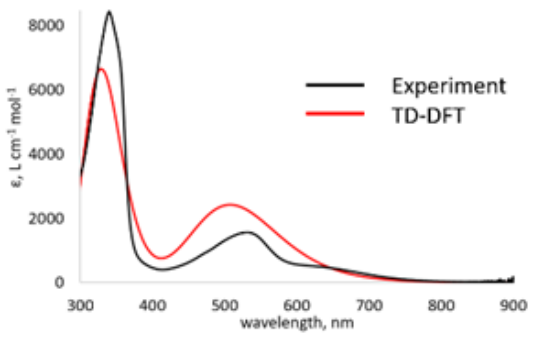

(b)

Figure 1. (a) ORTEP of $[1] \mathrm{BF}_{4}$. Thermal ellipsoids are drawn from $50 \%$ probability $\left([\mathbf{1}]^{+}\right)(\mathbf{b})$ Experimental and calculated absorption spectra of $[1]^{+}$in DMF solvent.

\section{Results and Discussion}

\subsection{Synthesis}

Complex [1] $]^{+}$was readily prepared from one equivalent of the $\mathrm{Cu}(\mathrm{I})$ starting $\left[\mathrm{Cu}(\mathrm{MeCN})_{4} \mathrm{BF}_{4}\right][37]$ and two equivalents of 2-pyridin-2-yl-quinoxaline (pq) [38] in acetonitrile. All operations were performed under a pure nitrogen atmosphere, using Schlenk and syringe techniques. $\left[\mathrm{Cu}(\mathrm{I})(\mathrm{MeCN})_{4} \mathrm{BF}_{4}\right][37]$ $1.0 \mathrm{mmol}$ were dissolved in $5 \mathrm{~mL}$ acetonitrile and after a few minutes, 2-pyridin-2-yl-quinoxaline (pq) [38] $2.0 \mathrm{mmol}$ dissolved in $10 \mathrm{~mL}$ acetonitrile was added and the mixture was stirred for $2 \mathrm{~h}$. After this time, a deep purple solution was formed. Then the solvent was evaporated to dryness. The product was isolated in crystalline form with a yield of $63 \%$. Calculated elemental analysis: $\mathrm{C}, 55.29 ; \mathrm{H}, 3.21 ; \mathrm{N}, 14.88$; Found: C 55.46, H, 3.49; N, 15.01.

Complex [1] $\mathbf{B F}_{4}$ was also characterized by X-ray crystallography (Figure 1a, Tables S1-S7), UV-visible (Figure 1b) ${ }^{1} \mathrm{H}-\mathrm{NMR}$ (Figure S1) and cyclic voltammetry. Although its crystal structure was reported before [39], we repeated it for accuracy reasons and for taking into consideration the different anion of the complex. Time dependent density functional theory (TD-DFT) calculations with the B3LYP functional adequately reproduce the key features of the absorption spectrum and, thus, allow a reliable band assignment (Figure 1b, Table S8). The absorption bands centered at $550 \mathrm{~nm}$ are attributed to metal to ligand charge transfer (MLCT) transitions of the $\mathrm{Cu}(\mathrm{I}) \mathrm{d}$ orbitals to the pq $\pi^{*}$ antibonding orbitals.

\subsection{Photocatalytic $\mathrm{H}_{2}$ Production}

The photocatalytic $\mathrm{H}_{2}$ production activity of [1] ${ }^{+}$was assessed in a multicomponent artificial photosynthesis system in $\mathrm{N}, \mathrm{N}$-dimethylformamide-water $\left(\mathrm{DMF}: \mathrm{H}_{2} \mathrm{O}\right)$ mixture, using fluorescein $(\mathrm{Fl})$ as a photosensitizer (PS) and triethanolamine (TEOA) as a sacrificial electron donor and the sample $\mathrm{pH}$ was 10.55. Under optimal conditions ([PS] $=0.3 \mathrm{mM},[1]^{+}=0.85 \mu \mathrm{M}$, [TEOA] $=0.5 \mathrm{M}$ in Ar saturated DMF: $\mathrm{H}_{2} \mathrm{O} 2: 8, v / v$ solution under $\lambda>400$ irradiation) $[1]^{+}$can photocatalyze $\mathrm{H}_{2}$ production efficiently, achieving $3564 \mathrm{TON}$ (turnover number) with respect to the catalyst after $24 \mathrm{~h}$ (Table 1). Importantly, 
$[1]^{+}$can also serve as a photocatalyst for water reduction in a fully aqueous solution, reaching $182 \mathrm{~mol}$ of $\mathrm{H}_{2}$ per mole of catalyst. Keeping concentrations of [1] ${ }^{+}$, Fl and TEOA unchanged, the effect of solvent on $\mathrm{H}_{2}$ evolution was investigated as shown in Figure 2a which compares the catalytic efficiencies of three different solvent mixtures, namely $\mathrm{H}_{2} \mathrm{O}, \mathrm{DMF} / \mathrm{H}_{2} \mathrm{O} 2: 8$ and $\mathrm{DMF} / \mathrm{H}_{2} \mathrm{O} 1 / 13$. Photocatalytic systems with [1] ${ }^{+}$as catalyst and CdTe quantum dots (QDs) as the photosensitizer showed a maximum performance of $132.53 \mathrm{TON}$ after $24 \mathrm{~h}$ with TEOA as the electron donor, while systems with ascorbic acid as electron donor were inactive (Table S9).

Table 1. Performance of the photocatalytic system under various conditions.

\begin{tabular}{ccccc}
\hline Catalyst & Photosensitizer & $\mathbf{e}^{-}$Donor & Solvent & Evolved $\mathbf{H}_{\mathbf{2}}$ \\
\hline$[\mathbf{1}]^{+}, \boldsymbol{\mu M}$ & Fluorescein, $\mathbf{m M}$ & Triethanolamine, $\mathbf{M}$ & $\mathbf{D M F}: \mathbf{H}_{\mathbf{2}} \mathbf{O}$ & $\mathbf{T O N}^{\mathbf{2 4} \mathbf{h}}$ \\
\hline 100 & 1 & 0.5 & $1: 2$ & 28.04 \\
10 & 1 & 0.5 & $1: 2$ & 154.96 \\
1 & 1 & 0.5 & $1: 2$ & 855.45 \\
0.1 & 1 & 0.5 & $1: 2$ & 1130.72 \\
1 & 2 & 0.5 & $1: 2$ & 381.85 \\
1 & 1.5 & 0.5 & $1: 2$ & 724.77 \\
1 & 0.8 & 0.5 & $1: 2$ & 204.83 \\
1 & 0.5 & 0.5 & $1: 2$ & 773.89 \\
1 & 0.3 & 0.5 & $1: 2$ & 791.50 \\
1 & 1 & 0.1 & $1: 2$ & 836.91 \\
1 & 1 & 1 & $1: 2$ & 781.31 \\
0.85 & 0.3 & 0.5 & $1: 4$ & 3564.31 \\
8.5 & 0.3 & 0.5 & $1: 4$ & 547.98 \\
0.85 & 0.3 & 0.5 & $1: 13$ & 2643.75 \\
0.85 & 0.3 & 0.5 & $1: 13$ & 1837.82 \\
0.85 & 0.3 & 0.5 & $\mathrm{H}_{2} \mathrm{O}$ & 182.00 \\
\hline
\end{tabular}

${ }^{1}$ In the presence of ca. $1 \mathrm{~mL}$ of mercury.

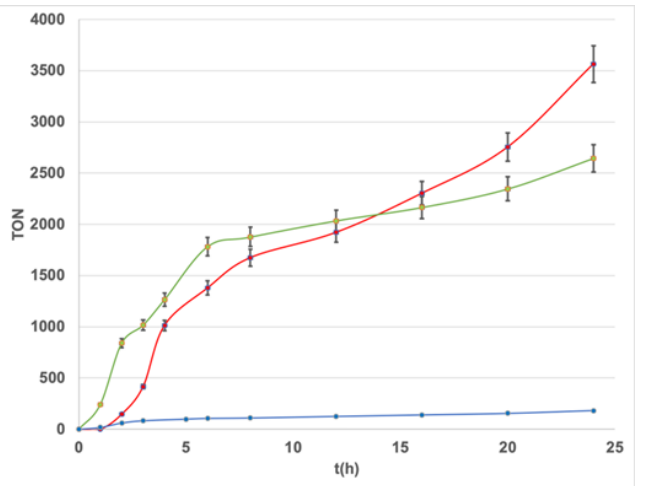

(a)

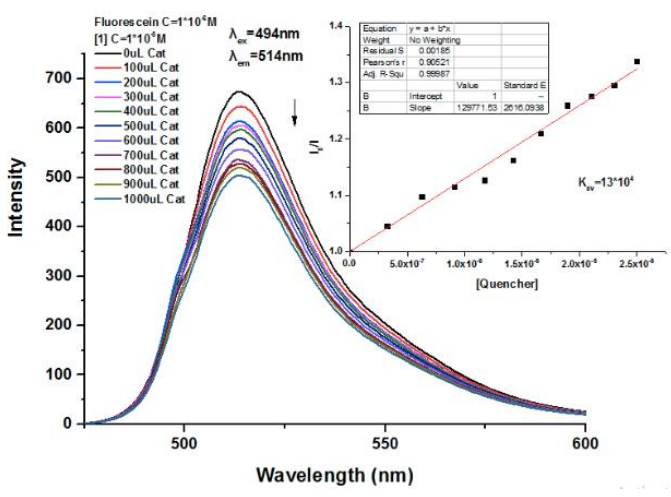

(b)

Figure 2. (a) Light-driven hydrogen production from system containing complex $[1]^{+}$as catalyst $\left(8.5^{*} 10^{-7} \mathrm{M}\right)$, Fl $0.3 \mathrm{mM}$, TEOA $(0.5 \mathrm{M})$ in DMF: $\mathrm{H}_{2} \mathrm{O}(1: 13)(10.0 \mathrm{~mL})$ (green), in DMF: $\mathrm{H}_{2} \mathrm{O}(2: 8)(10.0 \mathrm{~mL})$ (red) and in $\mathrm{H}_{2} \mathrm{O}$ (blue) (b) Photoluminescence spectra of fluorescein as a function of [1] ${ }^{+}$and Stern-Volmer plot of quenching by $[1]^{+}$.

Control experiments in the absence of light or any component of the system led to zero catalytic activity under the same conditions. In addition, mercury poisoning test was employed to investigate if catalytically active colloidal particles were formed during the catalytic process. Addition of mercury to this catalytic system resulted in a 30\% reduction of the catalytic activity after $24 \mathrm{~h}$ of irradiation (Table 1), suggesting that the complex acts as a molecular photocatalyst, even though hydrogen evolution is partly attributed to in situ formed heterogeneous species. 
In photocatalytic $\mathrm{H}_{2}$ evolution, the catalyst may accept electrons either from the excited PS or the reduced PS, resulting in oxidative and reductive quenching, respectively. The luminescence of the excited photosensitizer $\mathrm{FL}^{*}$, in a deaerated $\mathrm{H}_{2} \mathrm{O}$ solution of fluorescein, was plotted as a function of catalyst concentration and Stern-Volmer analysis yielded a quenching constant $\mathrm{k}_{\mathrm{sv}}=1.3^{*} 10^{5} \mathrm{M}^{-1}$, indicating that the excited fluorescein can provide the potential needed to drive reduction of the catalyst (Figure $2 b$ ). However, the reductive quenching possibly predominates the photocatalytic process, because the TEOA concentration is six orders of magnitude higher than the concentration of the catalyst.

Due to the non-innocent nature of the pq ligand and the proposed ligand centered proton reduction mechanism (vide infra), a zinc analogue of complex $[1]^{+},\left[\mathrm{Zn}(\mathrm{pq})_{2}\right]^{2+}$ was synthesized and was employed as a photocatalyst in identical conditions to complex $[1]^{+}$, in order to elucidate whether the process is entirely ligand centered or mediated by the participation of the metal center (Figure S2). The zinc complex showed no catalytic activity. In addition, photocatalytic hydrogen production experiments were performed using pq as a catalyst where the catalytic performance did not exceed 3 TON proving that copper is an essential component in the proton reduction process.

\subsection{Electrocatalytic Proton Reduction}

The cyclic voltammogram $(\mathrm{CV})$ of $[1]^{+}$recorded in DMF with $0.1 \mathrm{M}$ tetrabutylammonium hexafluorophosphate $\left(n-\mathrm{Bu}_{4} \mathrm{NPF}_{6}\right)$ as supporting electrolyte (Figure 3a) features an irreversible redox process at $-0.18 \mathrm{~V}$ vs. ferrocenium/ferrocene $\left(\mathrm{Fc}^{+} / \mathrm{Fc}\right)$, which may be assigned to $\mathrm{Cu}^{\mathrm{II}} / \mathrm{Cu}^{\mathrm{I}}$. Two irreversible reduction events at $-1.70 \mathrm{~V}$ and $-1.97 \mathrm{~V}$ are attributed mostly to the pq ligand with some contribution from the $\mathrm{Cu}$ metal center. The free ligand reduction potential in DMF is $-2.0 \mathrm{~V}$ vs. $\mathrm{Fc}^{+} / \mathrm{Fc}$ (Figure S3). The assignment of these reduction waves to the ligand-centered reduction processes is further supported by the calculated spin density of 0.18 on $\mathrm{Cu}$ at the reduced intermediate $[1]^{0}$, as well as by the fact that the homoleptic $\mathrm{Cu}(\mathrm{I})$ complex with 2,2'-biquinoline (bq) has a similar redox process at the same potential window, which is attributed to $\mathrm{bq} / \mathrm{bq}^{\bullet-}$ reduction [40]. The computationally derived oxidation and reduction potentials of $[1]^{+}$are $-0.25 \mathrm{~V},-1.77 \mathrm{~V}$ and $-2.18 \mathrm{~V}$, respectively, which supports a reliable peak assignment.

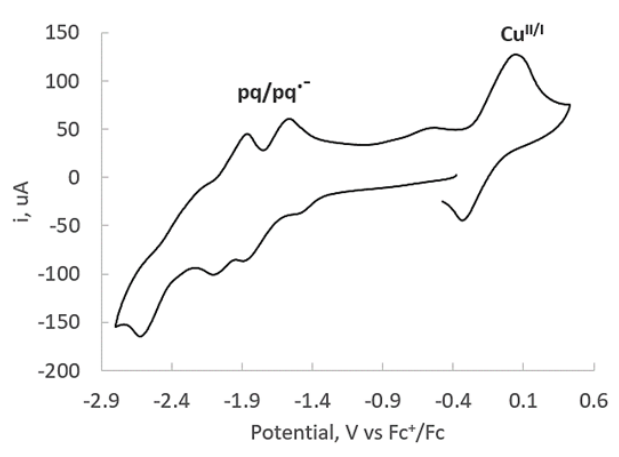

(a)

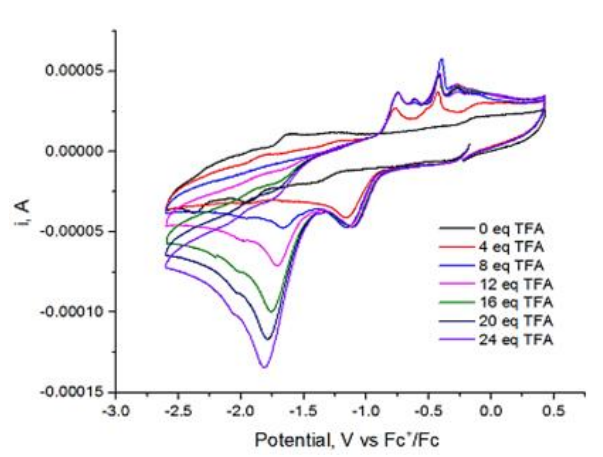

(b)

Figure 3. (a) Cyclic voltammogram (CV) of complex [1] $]^{+}(1 \mathrm{mM})$ in DMF solution of $n$-Bu4NPF6 (0.1 M) on a glassy carbon electrode at a scan rate of $0.1 \mathrm{~V} \mathrm{~s}-1$ (b) CVs of [1] $]^{+} 1 \mathrm{mM}$ in DMF (0.1 M Bu4NPF6) with increasing equivalents of TFA.

Subsequently, [1] ${ }^{+}$was investigated with respect to its activity for electrocatalytic $\mathrm{H}_{2}$ production. As displayed in Figure $3 b$, upon addition of trifluoroacetic acid $\left(\mathrm{TFA}, \mathrm{pKa} \mathrm{a}^{\mathrm{DMF}}=6.0\right)[41]$ in a DMF solution of [1] ${ }^{+}$, a new reduction peak appears at $-1.10 \mathrm{~V}$ and a significant catalytic current was observed over the potential of $-1.66 \mathrm{~V}$, attributed to catalytic $\mathrm{H}_{2}$ evolution. The overpotential of the catalyst was calculated [42] to be $720 \mathrm{mV}$, based on the reduction potential of TFA in a $5 \mathrm{mM}$ DMF solution was calculated to be $-0.94 \mathrm{~V}$ [43]. Several pieces of evidence suggest that the catalytic system is homogeneous. The linear dependence of catalytic current on the square of the scan rate (Figure $4 a, b$ ) 
indicates that the copper complex functions in a diffusion-controlled regime under the experimental conditions, and that it is a molecular catalyst. Also, rinse test experiment (Figure 4c) indicates that absorbed materials on the electrode surface are not catalytically active. Furthermore, the current increases linearly with an increase in the acid concentration (Figure $4 \mathrm{~d}$ ).

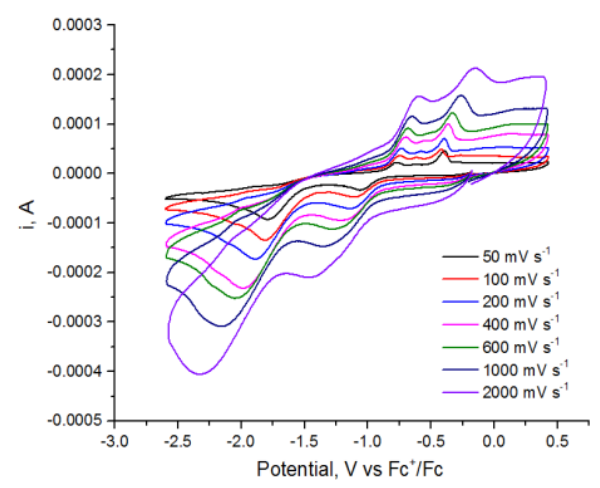

(a)

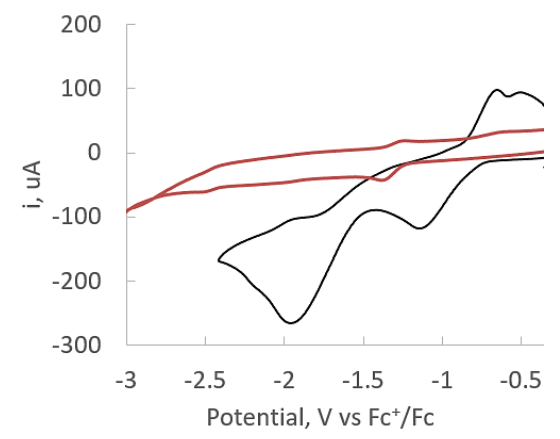

(c)

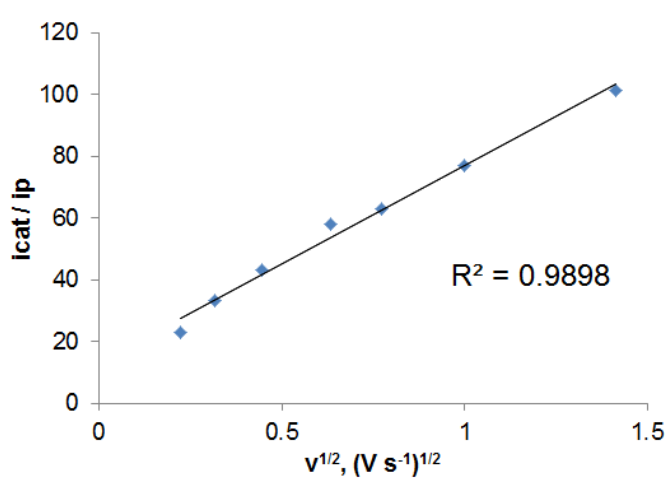

(b)

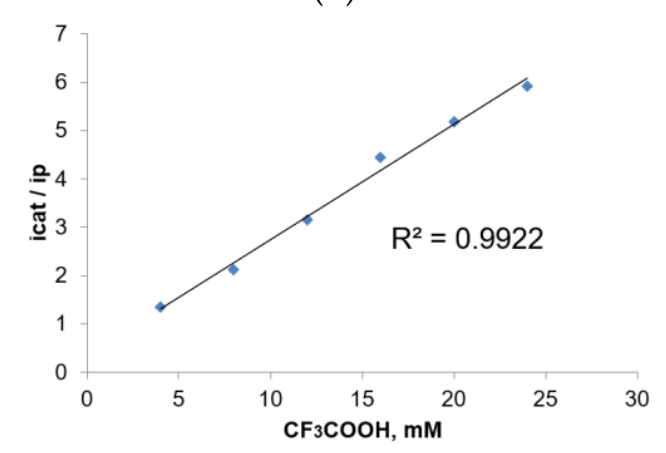

(d)

Figure 4. (a) $\mathrm{CVs}$ of $1 \mathrm{mM} \mathrm{[1]}]^{+}$in $0.1 \mathrm{M} \mathrm{Bu}_{4} \mathrm{NPF}_{6}$ DMF solution with 24 eq TFA at different scan rates (b) Plot of $i_{\text {cat }} / i_{p}$ vs the square root of the scan rate (c) CV of [1] ${ }^{+} 1 \mathrm{mM}$ in DMF $\left(0.1 \mathrm{M} \mathrm{Bu}_{4} \mathrm{NPF}_{6}\right)$ with $15 \mathrm{mM}$ TFA added (black) and a subsequent CV (red) using the same electrode after performing electrolysis at a potential of $-1.7 \mathrm{~V}$ for $5 \mathrm{~min}$, then rinsing with $\mathrm{DMF}$ and transfer to fresh DMF/0.1 M $\mathrm{Bu}_{4} \mathrm{NPF}_{6}$ solution without adding [1] ${ }^{+}$with $15 \mathrm{mM}$ TFA (d) Dependence of the catalytic current, $\mathrm{i}_{\text {cat }} / \mathrm{i}_{\mathrm{p}}$, on the concentration of TFA in a $1 \mathrm{mM}[1]^{+}$and $0.1 \mathrm{M} \mathrm{Bu}_{4} \mathrm{NPF}_{6}$ DMF solution.

The electrocatalytic activity of [1] ${ }^{+}$was also assessed in aqueous solution in the presence of acetic acid as a source of protons (Figure $5 \mathrm{a}, \mathrm{b}$ ). A very useful method to investigate the possibility of a concerted electron and proton transfer process (proton coupled electron transfer, PCET) instead of two separate consecutive electron transfer (ET) and proton transfer (PT) processes is the construction of the Pourbaix diagram, in which the reduction potential versus the $\mathrm{pH}$ of the solution is plotted [44]. The Pourbaix diagram (Figure $5 \mathrm{c}$ ) shows that the reduction potential of the first reduction peak shifts linearly with the $\mathrm{pH}$ value in the range of 2.5 to 6.0 , with a slope of $66.1 \mathrm{mV}$, which indicates that electron reduction is coupled with proton uptake. Similar ligand centered PCET processes have been reported for polypyridine copper proton reduction catalysts [24-27].

\subsection{Computational Study of the Catalytic Mechanism}

DFT calculations were performed, in an effort to provide further insight on the electrocatalytic mechanism by exploring the possible steps of the $\mathrm{H}_{2}$ formation. The computed structures of all the intermediates involved in the catalytic pathways are presented in the Supplementary Information. The proposed proton reduction mechanism derived from the calculated free energies of possible intermediates of the reaction pathway is shown in Figure 6a. 


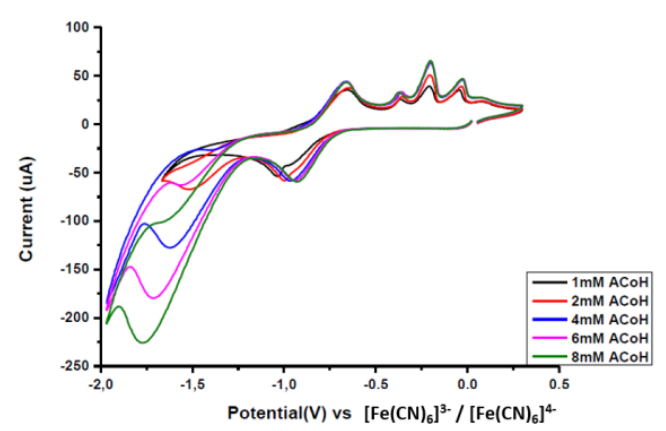

(a)

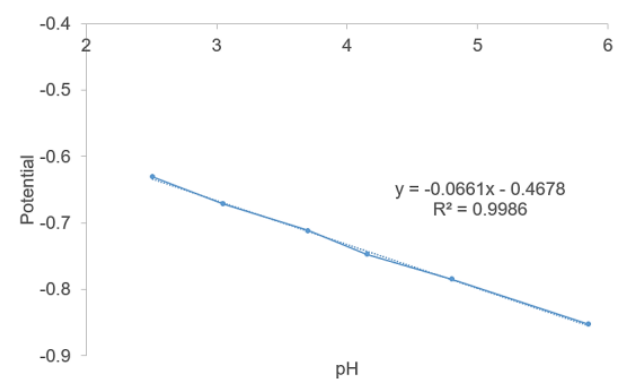

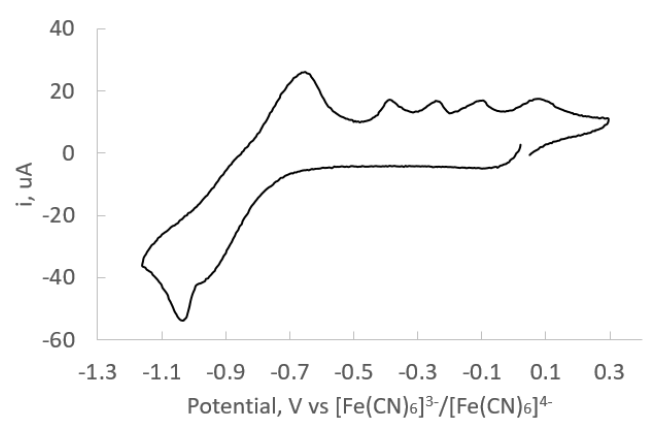

(b)

(c)

Figure 5. (a) CVs of $[1]^{+}(0.5 \mathrm{mM})$ in the presence of various concentrations of $\mathrm{AcOH}(1.0-8.0 \mathrm{mM})$ recorded in an aqueous solution of $\mathrm{NaCl}(0.1 \mathrm{M})$ on a glassy carbon electrode at a scan rate of $0.1 \mathrm{~V} \mathrm{~s}^{-1}$ (b) $\mathrm{CV}$ of [1] ${ }^{+}(0.5 \mathrm{mM})$ in the presence of $2 \mathrm{mM}$ of acetic acid recorded in an aqueous solution of $\mathrm{NaCl}$ $(0.1 \mathrm{M})$ on a glassy carbon electrode at a scan rate of $0.1 \mathrm{~V} \mathrm{~s}^{-1}$ in the potential window of 0.3 to $-1.1 \mathrm{~V}$ (c) Pourbaix diagram (reduction potential vs. $\mathrm{pH}$ ): the reduction potential of the first $\mathrm{CV}$ peak vs. $\left[\mathrm{Fe}(\mathrm{CN})_{6}\right]^{3-} /\left[\mathrm{Fe}(\mathrm{CN})_{6}\right]^{4-}$ shifts linearly with the $\mathrm{pH}$ value in the $\mathrm{pH}$ range of 2.5-6.0, with a slope of $0.066 \mathrm{mV}$ per $\mathrm{pH}$ unit. The respective $\mathrm{CVs}$ were recorded in aqueous solutions of $[1]^{+}(0.5 \mathrm{mM})$ in the presence of $\mathrm{CH}_{3} \mathrm{COOH} / \mathrm{CH}_{3} \mathrm{COONa}$ buffer.

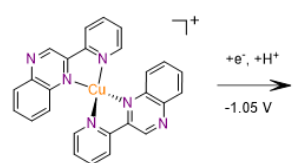

$[1]^{+}$

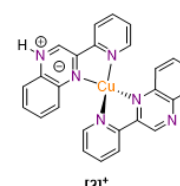

[2] ${ }^{+}$

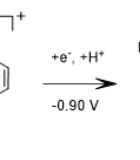

(1)
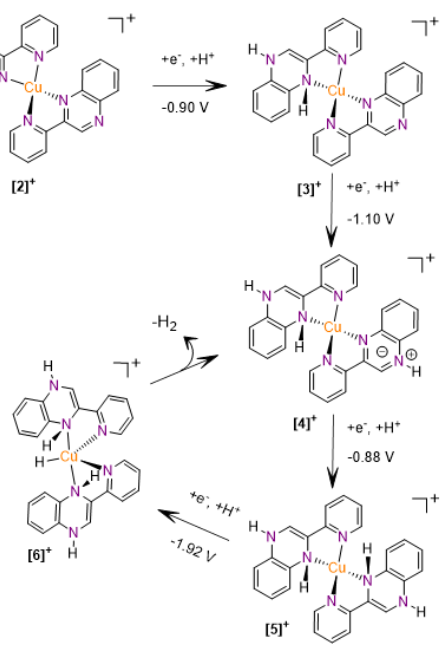

(a)

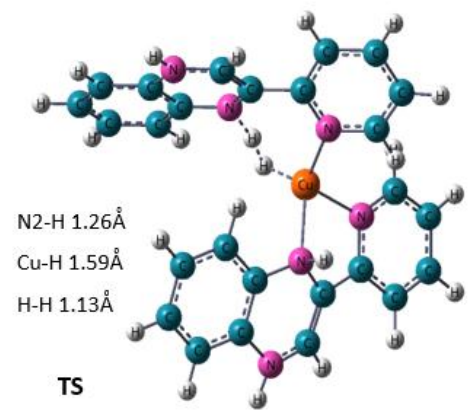

(b)

Figure 6. (a) Proposed mechanism for the electrocatalytic $\mathrm{H}_{2}$ formation by [1] ${ }^{+}$based on DFT calculations using the B3LYP-D3/6-311+g(2d,p) method for the calculation of redox potentials and protonation energies (b) Structure of the transition state (TS) for $\mathrm{H}_{2}$ formation.

In the presence of TFA ( $\mathrm{pKa}=6.0$ in $\mathrm{DMF}$ ) the first reduction to generate the doublet species $[2]^{+}$is a PCET process, in which ligand reduction is concomitant with a nitrogen atom protonation. 
Three different isomers can be considered in terms of whether the site of protonation is the coordinating pyridine nitrogen (N1), the coordinating quinoxaline nitrogen $(\mathrm{N} 2)$ or the non-coordinating quinoxaline nitrogen (N3) (Figure S5).

The $[\mathrm{Cu}-\mathrm{N} 3-\mathrm{H}]^{+}$isomer was found to be the most stable one, while the free energies of $[\mathrm{Cu}-\mathrm{N} 2-\mathrm{H}]^{+}$ and $[\mathrm{Cu}-\mathrm{N} 1-\mathrm{H}]^{+}$are 7.2 and $10.6 \mathrm{kcal} \mathrm{mol}^{-1}$ higher than that of $[\mathrm{Cu}-\mathrm{N} 3-\mathrm{H}]^{+}$, respectively. Protonation of $\mathrm{Cu}^{\mathrm{I}}$ to form a $\mathrm{Cu}^{\mathrm{III}}$ hydride was also considered, but the energy of this step is found to be $28.5 \mathrm{kcal} \mathrm{mol}^{-1}$ higher than the most stable species.

This redox peak assignment is also supported by the cyclic voltammetry data of the free ligand, where a new reduction peak at $-1.1 \mathrm{~V}$ appears in the presence of TFA (Figure S3).

A second PCET step to afford intermediate [3] ${ }^{+}$is feasible on the basis of thermodynamics with a calculated potential of $-0.90 \mathrm{~V}$. The most favourable protonation site when the N3 is already protonated is the N2 ligating atom, on the same quinoxaline ring, which takes a tetrahedral conformation, thus it maintains the $\mathrm{Cu}-\mathrm{N} 2$ bond as well as the N2-H bond. Protonation of the non-coordinating quinoxaline N3 is accompanied by reduction of the quinoxaline moiety under applied potential, which increases the basicity of the coordinating N2. Upon the second PCET, N2 protonation induces loss of the $\pi$-conjugation of the pyrazine ring, which is reflected in the calculated C-C and C-N bond lengths, and $\mathrm{N} 2$ now lies above the plane of the pyrazine $\mathrm{C}$ atoms without being dechelated from the metal $\left([3]^{+}\right.$, Figure S6). Other possible protonation sites and the corresponding relative free energies are shown in Figure S6. Notably, the formation of a $\mathrm{Cu}$ hydride is $30.2 \mathrm{kcal} \mathrm{mol}^{-1}$ energetically higher. Two further PCET processes result in protonation of the second quinoxaline ligand and the $4 \mathrm{H}^{+} / 4 \mathrm{e}^{-}$reduced intermediate $[5]^{+}$is generated. Since protonation of the ligating nitrogens induces weakening of the $\mathrm{Cu}-\mathrm{N}$ bonds, the possibility of [5] ${ }^{+}$decomposition was examined, but was found unfavorable (Figure S7). In the presence of acid, five oxidation peaks appear at the anodic scan of the cyclic voltammogram at $-0.70 \mathrm{~V},-0.62 \mathrm{~V},-0.41$ and $-0.26 \mathrm{~V}$, which can be assigned to the four ligand centered redox processes, and at $-0.07 \mathrm{~V}$ which is attributed to $\mathrm{Cu}^{\mathrm{I}} / \mathrm{Cu}^{\mathrm{II}}$ oxidation (Figure $3 \mathrm{~b}$ ). Cyclic voltammogram within a narrow potential region $(0.3$ to $-1.2 \mathrm{~V})$ to prevent the formation of $\mathrm{Cu}(0)$ species, show that the four anodic peaks are attributed to the first reduction peak (Figure $5 \mathrm{~b}$ ). The reduction potential of intermediate $[5]^{+}$to generate $\mathrm{Cu}(0)$ species is calculated to be $-2.58 \mathrm{~V}$, while a metal centered PCET at a calculated potential of $-1.92 \mathrm{~V}$ (experimental $-1.66 \mathrm{~V}$ ) in the presence of TFA affords a trigonal pyramidal $\mathrm{Cu}(\mathrm{II})$ hydride, $[6]^{+}$, which is proposed to be the $\mathrm{H}_{2}$ evolving species. [6] ${ }^{+}$can evolve $\mathrm{H}_{2}$ via a low energy $\left(+6.8 \mathrm{kcal} \mathrm{mol}^{-1}\right)$ transition state (TS, Figure $6 \mathrm{~b}$ ) with a single imaginary frequency at 1245.6, that corresponds to $\mathrm{H}_{2}$ formation, as confirmed by IRC (integrated reaction coordinates) calculation. The energy coordinate diagram of the hydrogen evolution reaction was generated from the free energy change of each step in the catalytic cycle (Figure 7).

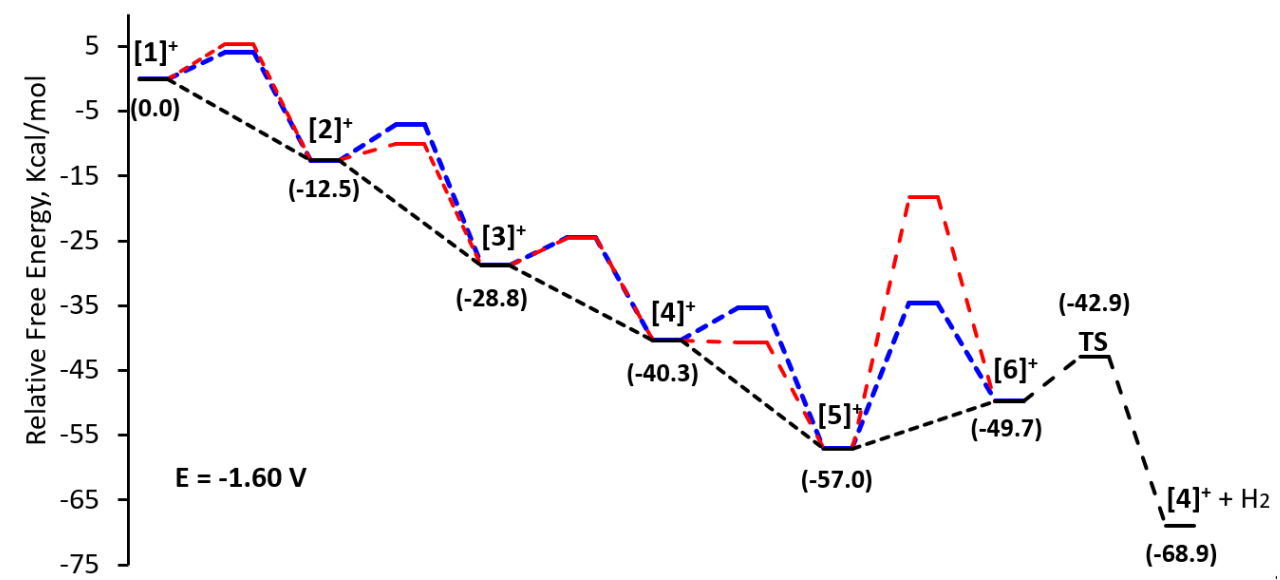

Figure 7. Free energy diagram depicting the possible electron transfer-followed by proton transfer (ET-PT, blue), proton transfer-followed by electron transfer (PT-ET, red) and concerted proton coupled electron transfer (PCET, black) processes of the $\mathrm{H}_{2}$ evolution catalytic pathway. 


\section{Conclusions}

We have presented that the $\mathrm{Cu}(\mathrm{I})$ diimine complex $[1]^{+}$can serve as a molecular photocatalyst for water reduction in combination with fluorescein as a photosensitizer and triethanolamine as a sacrificial electron donor achieving 3564 turnovers, after $24 \mathrm{~h}$ of irradiation. Mechanistic studies based on electrochemical experiments and DFT calculations support that protonation of the nitrogen atoms of the pq ligand via consecutive PCET processes allows more anodic reduction potentials for the $\mathrm{Cu}$ (II)-hydride formation and lowers the overpotential needed for proton reduction. Furthermore, the non-ligating quinoxaline nitrogen also increases the stability of the catalyst under reductive conditions and, thus, the present study provides important guidelines for future robust catalysts design. Detailed mechanistic studies using spectroelectrochemistry experiments are at the center of ongoing work, as well as the development of polydentate quinoxaline containing ligands, that are expected to further stabilize the $\mathrm{Cu}(\mathrm{I})$ species.

\section{Materials and Methods}

\subsection{General Information}

Reagents (starting materials, solvents) used in the experiments were purchased from Sigma Aldrich (Darmstadt, Germany) Merck (Darmstadt, Germany), Alfa Aesar (Heysham, Lancashire, UK) and Panreac Applichem (Barcelona, Spain). It was at least analytical grade and underwent further purification, where it was necessary to carry out the experiments. The solvents used to measure the absorption and emission spectra were of spectroscopic purity and originated from the above companies. Also, the water used in the experiments was from the Milli-Q instrument. In complex synthesis [39], the reagents that were used were purchased from the above companies.

Absorption spectra were measured on a Cary 300 (Varian Inc.-Agilent Technologies, Grenoble, France) or a U-2000 (Hitachi, Berkshire, United Kingdom ) spectrophotometers at $25^{\circ} \mathrm{C}$. Quartz alveoli were used with a stopper, a $1.00 \mathrm{~cm}$ optical path. Emission spectra were measured on a RF-5301PC spectrophotometer (Shimadzu, Hesse, Germany). Quartz alveoli were used with a $1.00 \mathrm{~cm}$ optical path, using the software OriginPro 9.0 (Arezzo, Italia). ${ }^{1} \mathrm{H}-\mathrm{NMR}$ spectra were measured on a Unity Plus 300/54 spectrophotometer (Varian, Grenoble, France).

For the X-ray diffraction studies, suitable crystals covered with paratone-N oil were placed onto the tips of glass fibers or scooped up in cryo-loops at the end of a copper pin and transferred to a goniostat for data collection with a SuperNova A diffractometer (Oxford Diffraction, Frankfurt, Germany,) equipped with a CCD area detector and a graphite monochromator utilizing Mo-K $\alpha$ radiation $(\lambda=0.71073 \AA)$. Empirical absorption corrections were applied using CrysAlis RED software [45] (multi-scan based on symmetry-related measurements). Structures were solved using SIR92 [46] and refined on $F^{2}$ using full-matrix least squares with SHELXL97 [47]. Software packages used: CrysAlis CCD for data collection, CrysAlis RED for cell refinement and data reduction, WINGX for geometric calculations [48] and MERCURY [49] for molecular graphics. The program SQUEEZE [50], a part of the PLATON crystallographic software package, was used to remove contribution of highly disordered solvent molecules. All non-hydrogen atoms were refined anisotropically, whereas the hydrogen atoms were placed in calculated, ideal positions and refined as riding atoms with relative isotropic displacement parameters. Unit cell data and structure refinement details are listed in Table S2.

Photocatalysis experiments were performed in special led headlamps where the emitted radiation is in the range of the visible radiation spectrum $(\lambda>400 \mathrm{~nm})$. The samples were irradiated for at least $72 \mathrm{~h}$ until the maximum performance of each system was found. The gaseous composition of the mixture and therefore the hydrogen detection was done by gas chromatography. The gas chromatograph was a 430-GC type (Bruker, Karlsruhe, Germany) equipped with a thermal conductivity detector (TCD) and operated under the following conditions: carrier gas: nitrogen, oven temperature $70{ }^{\circ} \mathrm{C}$, detector temperature $150{ }^{\circ} \mathrm{C}$, injector temperature $80^{\circ} \mathrm{C}$, molecular sieves column $5 \AA$. The analysis of the chromatograms was done using the Galaxie software (Varian). The flask under the photocatalyst 
experiment was degassed by argon for $15 \mathrm{~min}$ and the system was sealed and illuminated for as long as the experiment lasts to find the maximum hydrogen output. The hydrogen produced is measured by integration of the chromatographic peaks and the quantification of the amount of hydrogen was based on calibration using $\mathrm{Zn}$ in aqueous $\mathrm{HCl}$ solution. Turnover number (TON) is used to quantify catalyst performance and represents the overall number of moles of $\mathrm{H}_{2}$ produced upon irradiation of a photocatalytic system per mole of catalyst in the system.

\subsection{Synthesis}

$\left[\mathrm{Zn}(\mathrm{pq})_{2}\right] \mathrm{Cl}_{2}$ was synthesized with the following procedure: $\mathrm{ZnCl}_{2}(1.0 \mathrm{mmol})$ was dissolved in $\mathrm{EtOH}(5 \mathrm{~mL})$. After a few minutes, 2-pyridin-2-yl-quinoxaline (pq, $2.0 \mathrm{mmol}$ ) dissolved in EtOH $(10 \mathrm{~mL})$ was added. The mixture was stirred for $2 \mathrm{~h}$. Almost immediately white powder appeared. The solution filtered off, washed with ethanol and dried, with a yield of $73 \%$. Elemental Anal. Calc: C, 66.08; H, 3.78; N, 17.51; Found: C 66.12, H, 3.90; N, $17.35{ }^{1} \mathrm{H}-\mathrm{NMR}$ peaks $\mathrm{CDCl}_{3}$ : 7.49 (s, 2H), $7.78(\mathrm{~d}, 4 \mathrm{H}), 7.94(\mathrm{~s}, 2 \mathrm{H}), 8.19(\mathrm{~d}, 6 \mathrm{H}), 8.62(\mathrm{t}, 2 \mathrm{H}), 8.81(\mathrm{~s}, 2 \mathrm{H})$.

CdTe QDs were prepared as reported previously [51] and the A-F notation in Table S9 refers to the QDs' preparation time according to this reference. A $50 \mathrm{~mL}$ aqueous solution of $\mathrm{Cd}\left(\mathrm{CH}_{3} \mathrm{COO}\right)_{2} \bullet 2 \mathrm{H}_{2} \mathrm{O}$ $(0.2 \mathrm{mmol})$, thioglycolic acid $90 \%(18 \mu \mathrm{L}), \mathrm{K}_{2} \mathrm{TeO}_{3}(0.04 \mathrm{mmol})$ and $\mathrm{NaBH}_{4}(80 \mathrm{mg})$ was refluxed under open-air conditions for (A) $15 \mathrm{~min},(\mathrm{~B}) 30 \mathrm{~min},(\mathrm{C}) 1 \mathrm{~h}$, (D) $3 \mathrm{~h},(\mathrm{E}) 7 \mathrm{~h}$ or (F) $13 \mathrm{~h}$.

\subsection{Cyclic Voltammetry}

All cyclic voltammetry (CV) measurements were recorded using an AFCBP1 (Pine Instrument Company, Lyon, France) and using the Aftermath Data Organizer software version 1.4.7881. Experiments were conducted in a three-electrode single-compartment cell with a glassy carbon working electrode, $\mathrm{Ag} / \mathrm{AgCl}$ reference electrode and $\mathrm{Pt}$ counter-electrode at room temperature and using degassed solutions by purging with $\mathrm{N}_{2}$. All measurements were performed in $\mathrm{N}, \mathrm{N}$-dimethylformamide (DMF) in the presence of $0.1 \mathrm{M}$ tetrabutylammonium hexafluoro-phosphate $\left(n-\mathrm{Bu}_{4} \mathrm{NPF}_{6}\right)$ as a supporting electrolyte and ferrocenium/ferrocene $\left(\mathrm{Fc}^{+} / \mathrm{Fc}\right)$ redox couple was used as an internal potential reference.

\subsection{Theoretical Studies}

Geometry optimizations were carried out using the B3LYP density functional [52,53] in combination with the 6-31 $\mathrm{g}(\mathrm{d}, \mathrm{p})$ basis set [54,55] as implemented in the Gaussian16 software package [56]. The choice of this functional was made based on agreement between the calculated optimized geometry and the experimentally defined structure (Table S10) as well as on its successful implementation in previous studies on copper-based catalysts. Gibbs free energies were calculated as single-point corrections on the optimized structures employing the larger basis set 6-311+g $(2 \mathrm{~d}, \mathrm{p})$ and D3 dispersion corrections [57] to obtain a more accurate value of the absolute free energy of each species. The solvent effects were considered through single-point energy calculations using the SMD continuum solvation model [58]. Frequency calculations were performed on all the optimized structures at the same level of theory, to identify all the stationary points as minima (zero imaginary frequency) or transition states (only one imaginary frequency) and to obtain Gibbs free energy corrections at 298.15 K. Time-dependent DFT (TD-DFT) calculations were performed to simulate the absorption spectra of [1] ${ }^{+}$.

The reduction potential was determined using the equation $\mathrm{E}=\Delta \mathrm{G}^{\mathrm{o}} / \mathrm{nF}-\mathrm{E}\left(\mathrm{Fc}^{+} / \mathrm{Fc}^{0}\right)$, where the $\mathrm{E}\left(\mathrm{Fc}^{+} / \mathrm{Fc}^{0}\right)$ standard ferrocene couple $\left(\mathrm{Fc}^{+} / \mathrm{Fc}^{0}=4.988\right)$ [59]. Trifluoroacetic acid $\left(\mathrm{pKa}{ }^{\mathrm{TFA}}=6.0\right)$ calculated at the same level of theory was used for the calculation of the free energies of each protonation step through following equation: $\mathrm{A}+\mathrm{CF}_{3} \mathrm{COOH} \rightarrow \mathrm{AH}^{+}+\mathrm{CF}_{3} \mathrm{COO}^{-}, \mathrm{pKa}^{\mathrm{AH}+}=\Delta \mathrm{G}^{\mathrm{o}} / 1.364+\mathrm{pKa}^{\mathrm{TFA}}$. The redox potential for the PCET processes, $\mathrm{A}+\mathrm{e}^{-}+\mathrm{H}^{+} \rightarrow \mathrm{AH}$, was calculated using the equation, $\mathrm{E}(\mathrm{A} / \mathrm{AH})=\mathrm{E}^{\circ}\left(\mathrm{A} / \mathrm{A}^{-}\right)+\mathrm{RT} \ln (10)\left(\mathrm{pKa}^{\mathrm{AH}}-\mathrm{pKa}^{\mathrm{TFA}}\right)($ Table S11).

Supplementary Materials: The following are available online at http://www.mdpi.com/2073-4344/10/11/1302/s1, Figure S1: ${ }^{1} \mathrm{H}-\mathrm{NMR}$ of $[1] \mathrm{BF}_{4}$ in $\mathrm{CDCl}_{3}$, Figure S2: ${ }^{1} \mathrm{H}-\mathrm{NMR}$ of $\left[\mathrm{Zn}(\mathrm{pq})_{2}\right]^{2+}$ in $\mathrm{CDCl}_{3}$, Figure S3: Cyclic 
voltammograms (CVs) of the pq ligand $(5.0 \mathrm{mM})$ in the absence (black curve) and the presence (coloured curves) of $1 \mathrm{mM}$ (red), $2 \mathrm{mM}$ (blue) and $4 \mathrm{mM}$ (purple) of TFA recorded in a DMF solution of $\mathrm{n}-\mathrm{Bu}_{4} \mathrm{NPF}_{6}(0.1 \mathrm{M})$ on a glassy carbon electrode at a scan rate of $0.1 \mathrm{~V} \mathrm{~s}^{-1}$, Figure S4: Absorption spectra of [1] $\mathrm{BF}_{4}$ in $\mathrm{H}_{2} \mathrm{O}$ :DMF 1:8 mixture with $\mathrm{C}=2^{*} 10^{-4} \mathrm{M}$ under visible light irradiation over a period of $24 \mathrm{~h}$, Figure S5: Relative free energies of the $1 \mathrm{H}^{+}$protonated and $1 \mathrm{e}^{-}$reduced species [2] tautomers, Figure S6: Relative free energies of the $2 \mathrm{H}^{+}$protonated and $2 \mathrm{e}^{-}$reduced species [3] ${ }^{+}$tautomers, Figure S7: Possible decomposition pathways of the intermediate [5] ${ }^{+}$in water, Figure S8: Relative free energies of the $3 \mathrm{H}^{+}$protonated and $3 \mathrm{e}^{-}$reduced species $[4]^{+}$tautomers, Figure S9: Relative free energies of the $4 \mathrm{H}^{+}$protonated and $4 \mathrm{e}^{-}$reduced species [5] ${ }^{+}$tautomers, Figure S10: Higher occupied molecular orbital diagrams of the catalytic intermediates and spin densities on $\mathrm{Cu}(\rho \mathrm{Cu})$ of intermediates with unpaired electrons, Table S1: Crystallographic data for complex [1]BF 4 , Table S2: Selected bond distances $(\AA)$ and angles $\left({ }^{\circ}\right)$ for $[1] \mathrm{BF}_{4}$, Table S3: Crystal data and structure refinement for C26 H18 B Cu F4 N6 at $100 \mathrm{~K}$, Table S4: Atomic coordinates $\left(\times 10^{4}\right)$ and equivalent isotropic displacement parameters $\left(\AA^{2} \times 10^{3}\right)$ for C26 H18 B Cu F4 $\mathrm{N} 6$ at $100 \mathrm{~K}$ with estimated standard deviations in parentheses, Table S5: Anisotropic displacement parameters $\left(\AA^{2} \times 10^{3}\right)$ for C26 H18 B Cu F4 N6 at $100 \mathrm{~K}$ with estimated standard deviations in parentheses, Table S6: Bond lengths [̊̊] for C26 H18 B Cu F4 N6 at $100 \mathrm{~K}$ with estimated standard deviations in parentheses, Table S7: Bond angles $\left[{ }^{\circ}\right]$ for $\mathrm{C} 26 \mathrm{H} 18 \mathrm{~B} \mathrm{Cu} \mathrm{F} 4 \mathrm{~N} 6$ at $100 \mathrm{~K}$ with estimated standard deviations in parentheses, Table S8: Electronic transitions of $\left[\mathrm{Cu}(\mathrm{pq})_{2}\right]^{+}$calculated with the TDDFT method, Table S9: Performance of the photocatalytic systems with $[1]^{+}$as catalyst, different CdTe QDs as the photosensitizer and different $\mathrm{e}^{-}$donors in DMF: $\mathrm{H}_{2} \mathrm{O}$ 1:2 solvent mixture, Table S10: Comparison of the experimental (crystal structure) and DFT calculated (B3LYP/6-31G gas phase) values of selected structural parameters of $\left[\mathrm{Cu}(\mathrm{pq})_{2}\right] \mathrm{BF}_{4}\left([1] \mathrm{BF}_{4}\right)$, Table S11: The free energy of $\mathrm{H}_{2}$ self-elimination from $\mathrm{AH}_{2}$ was calculated from the following equations.

Author Contributions: Conceptualization, C.A.M.; methodology, M.D., D.T., C.A.M.; synthesis, G.I., F.K., A.Z.; photocatalytic experiments, F.K.; electrocatalytic experiments, M.D., G.I.; Single crystal X-ray crystallography, C.P.; DFT calculations, M.D., D.T.; investigation, M.D.; resources, M.D.; data curation, M.D., F.K.; writing-review and editing, M.D.; supervision, C.A.M., D.T.; project administration, C.A.M. All authors have read and agreed to the published version of the manuscript.

Funding: Special Research Account of NKUA (No: 16672), Hellenic Foundation for Research and Innovation (HFRI) under the HFRI PhD Fellowship grant 16199, Operational Programme «Human Resources Development, Education and Lifelong Learning" in the context of the project "Strengthening Human Resources Research Potential via Doctorate Research" (MIS-5000432), implemented by the State Scholarships Foundation (IK $\Upsilon$ ).

Acknowledgments: We gratefully acknowledge financial support from the Special Research Account of NKUA (No: 16672). M.D.: The research work was supported by the Hellenic Foundation for Research and Innovation (HFRI) under the HFRI PhD Fellowship grant 16199. F.K. thanks the co-funding by Greece and the European Union (European Social Fund-ESF) through the Operational Programme «Human Resources Development, Education and Lifelong Learning" in the context of the project "Strengthening Human Resources Research Potential via Doctorate Research" (MIS-5000432), implemented by the State Scholarships Foundation (IK $\Upsilon$ ).

Conflicts of Interest: The authors declare no conflict of interest.

\section{References}

1. Paria, S.; Reiser, O. Copper in Photocatalysis. ChemCatChem 2014, 6, 2477-2483. [CrossRef]

2. Chen, Z.; Meyer, T.J. Copper(II) Catalysis of Water Oxidation. Angew. Chem. Int. Ed. 2013, 52, 700-703. [CrossRef] [PubMed]

3. Casitas, A.; Ribas, X. The role of organometallic copper(III) complexes in homogeneous catalysis. Chem. Sci. 2013, 4, 2301. [CrossRef]

4. $\quad$ Liu, S.; Lei, Y.-J.; Xin, Z.-J.; Lu, Y.-B.; Wang, H.-Y. Water splitting based on homogeneous copper molecular catalysts. J. Photochem. Photobiol. A 2018, 355, 141-151. [CrossRef]

5. Sandroni, M.; Pellegrin, Y.; Odobel, F. Heteroleptic bis-diimine copper(I) complexes for applications in solar energy conversion. Comptes Rendus Chim. 2016, 19, 79-93. [CrossRef]

6. Mejía, E.; Luo, S.-P.; Karnahl, M.; Friedrich, A.; Tschierlei, S.; Surkus, A.-E.; Junge, H.; Gladiali, S.; Lochbrunner, S.; Beller, M. A Noble-Metal-Free System for Photocatalytic Hydrogen Production from Water. Chem. Eur. J. 2013, 19, 15972-15978. [CrossRef]

7. Kavan, L.; Saygili, Y.; Freitag, M.; Zakeeruddin, S.M.; Hagfeldt, A.; Grätzel, M. Electrochemical Properties of $\mathrm{Cu}(\mathrm{II} / \mathrm{I})$-Based Redox Mediators for Dye-Sensitized Solar Cells. Electrochim. Acta 2017, 227, $194-202$. [CrossRef]

8. Magni, M.; Biagini, P.; Colombo, A.; Dragonetti, C.; Roberto, D.; Valore, A. Versatile copper complexes as a convenient springboard for both dyes and redox mediators in dye sensitized solar cells. Coord. Chem. Rev. 2016, 322, 69-93. [CrossRef] 
9. Muthuramalingam, S.; Khamrang, T.; Velusamy, M.; Mayilmurugan, R. Catalytic fixation of atmospheric carbon dioxide by copper(II) complexes of bidentate ligands. Dalton Trans. 2017, 46, 16065-16076. [CrossRef]

10. Liu, W.; Huang, H.; Ouyang, T.; Jiang, L.; Zhong, D.; Zhang, W.; Lu, T. A Copper(II) Molecular Catalyst for Efficient and Selective Photochemical Reduction of $\mathrm{CO}_{2}$ to $\mathrm{CO}$ in a Water Containing System. Chem. Eur. J. 2018, 24, 4503-4508. [CrossRef]

11. Barnett, S.M.; Goldberg, K.I.; Mayer, J.M. A soluble copper-bipyridine water-oxidation electrocatalyst. Nature Chem. 2012, 4, 498-502. [CrossRef] [PubMed]

12. Zhang, T.; Wang, C.; Liu, S.; Wang, J.-L.; Lin, W. A Biomimetic Copper Water Oxidation Catalyst with Low Overpotential. J. Am. Chem. Soc. 2014, 136, 273-281. [CrossRef] [PubMed]

13. Zhang, M.-T.; Chen, Z.; Kang, P.; Meyer, T.J. Electrocatalytic Water Oxidation with a Copper(II) Polypeptide Complex. J. Am. Chem. Soc. 2013, 135, 2048-2051. [CrossRef]

14. Ramakrishnan, S.; Balamurugan, J.; Vinothkannan, M.; Kim, A.R.; Sengodan, S.; Yoo, D.J. Nitrogen-doped graphene encapsulated FeCoMoS nanoparticles as advanced trifunctional catalyst for water splitting devices and zinc-air batteries. Appl. Catal. B 2020, 279, 119381. [CrossRef]

15. Sathiskumar, C.; Ramakrishnan, S.; Vinothkannan, M.; Rhan Kim, A.; Karthikeyan, S.; Yoo, D.J. Nitrogen-Doped Porous Carbon Derived from Biomass Used as Trifunctional Electrocatalyst toward Oxygen Reduction, Oxygen Evolution and Hydrogen Evolution Reactions. Nanomaterials 2019, 10, 76. [CrossRef] [PubMed]

16. Elayappan, V.; Shanmugam, R.; Chinnusamy, S.; Yoo, D.J.; Mayakrishnan, G.; Kim, K.; Noh, H.S.; Kim, M.K.; Lee, $\mathrm{H}$. Three-dimensional bimetal TMO supported carbon based electrocatalyst developed via dry synthesis for hydrogen and oxygen evolution. Appl. Surf. Sci. 2020, 505, 144642. [CrossRef]

17. Kügler, M.; Scholz, J.; Kronz, A.; Siewert, I. Copper complexes as catalyst precursors in the electrochemical hydrogen evolution reaction. Dalton Trans. 2016, 45, 6974-6982. [CrossRef]

18. Liu, X.; Cui, S.; Sun, Z.; Du, P. A Robust and Highly Active Copper-Based Electrocatalyst for Hydrogen Production at Low Overpotential in Neutral Water. Chem. Comm. 2015, 51, 12954-12957. [CrossRef]

19. Zhang, P.; Wang, M.; Chen, H.; Liang, Y.; Sun, J.; Sun, L. A Cu-Based Nanoparticulate Film as Super-Active and Robust Catalyst Surpasses Pt for Electrochemical $\mathrm{H}_{2}$ Production from Neutral and Weak Acidic Aqueous Solutions. Adv. Energy Mater. 2016, 6, 1502319. [CrossRef]

20. Zhao, J.; Tran, P.D.; Chen, Y.; Loo, J.S.C.; Barber, J.; Xu, Z.J. Achieving High Electrocatalytic Efficiency on Copper: A Low-Cost Alternative to Platinum for Hydrogen Generation in Water. ACS Catal. 2015, 5, 4115-4120. [CrossRef]

21. Du, J.; Wang, J.; Ji, L.; Xu, X.; Chen, Z. A Highly Active and Robust Copper-Based Electrocatalyst toward Hydrogen Evolution Reaction with Low Overpotential in Neutral Solution. ACS Appl. Mater. Interfaces 2016, 8, 30205-30211. [CrossRef] [PubMed]

22. Liu, X.; Zheng, H.; Sun, Z.; Han, A.; Du, P. Earth-Abundant Copper-Based Bifunctional Electrocatalyst for Both Catalytic Hydrogen Production and Water Oxidation. ACS Catal. 2015, 5, 1530-1538. [CrossRef]

23. Fan, M.; Gao, R.; Zou, Y.-C.; Wang, D.; Bai, N.; Li, G.-D.; Zou, X. An efficient nanostructured copper(I) sulfide-based hydrogen evolution electrocatalyst at neutral pH. Electrochim. Acta 2016, 215, 366-373. [CrossRef]

24. Wang, J.; Li, C.; Zhou, Q.; Wang, W.; Hou, Y.; Zhang, B.; Wang, X. Photocatalytic hydrogen evolution by $\mathrm{Cu}(\mathrm{II})$ complexes. Dalton Trans. 2016, 45, 5439-5443. [CrossRef] [PubMed]

25. Zhang, P.; Wang, M.; Yang, Y.; Yao, T.; Sun, L. A Molecular Copper Catalyst for Electrochemical Water Reduction with a Large Hydrogen-Generation Rate Constant in Aqueous Solution. Angew. Chem. 2014, 126, 14023-14027. [CrossRef]

26. Liao, R.-Z.; Wang, M.; Sun, L.; Siegbahn, P.E.M. Mechanism of Hydrogen Evolution in Cu(bztpen)—Catalysed Water Reduction: A DFT Study. Dalton Trans. 2015, 44, 9736-9739. [CrossRef]

27. Ekanayake, D.M.; Kulesa, K.M.; Singh, J.; Kpogo, K.K.; Mazumder, S.; Schlegel, H.B.; Verani, C.N. A pentadentate nitrogen-rich copper electrocatalyst for water reduction with $\mathrm{pH}$-dependent molecular mechanisms. Dalton Trans. 2017, 46, 16812-16820. [CrossRef]

28. Lei, H.; Fang, H.; Han, Y.; Lai, W.; Fu, X.; Cao, R. Reactivity and Mechanism Studies of Hydrogen Evolution Catalyzed by Copper Corroles. ACS Catal. 2015, 5, 5145-5153. [CrossRef] 
29. Haddad, A.Z.; Cronin, S.P.; Mashuta, M.S.; Buchanan, R.M.; Grapperhaus, C.A. Metal-Assisted Ligand-Centered Electrocatalytic Hydrogen Evolution upon Reduction of a Bis (thiosemicarbazonato) $\mathrm{Cu}$ (II) Complex. Inorg. Chem. 2017, 56, 11254-11265. [CrossRef]

30. Fang, T.; Lu, H.-X.; Zhao, J.-X.; Zhan, S.-Z.; Lv, Q.-Y. A new copper(I)-triazenido electro-catalyst for catalyzing hydrogen evolution from acetic acid and water. J. Mol. Catal. A Chem. 2015, 396, 304-309. [CrossRef]

31. Beyene, B.B.; Das, K.; Kerayu, B.A.; Datta, A.; Hung, C.-H. Electrocatalytic $\mathrm{H}_{2}$ evolution of a Schiff-base assisted $\mathrm{Cu}(\mathrm{II})$ derivative as catalyst on homogeneous and heterogeneous phase. Catal. Commun. 2019, 119, 111-114. [CrossRef]

32. Cao, J.-P.; Fang, T.; Fu, L.-Z.; Zhou, L.-L.; Zhan, S.-Z. First mononuclear copper(II) electro-catalyst for catalyzing hydrogen evolution from acetic acid and water. Int. J. Hydrog. Energy 2014, 39, 13972-13978. [CrossRef]

33. Fu, L.-Z.; Fang, T.; Zhou, L.-L.; Zhan, S.-Z. A mononuclear copper electrocatalyst for both water reduction and oxidation. RSC Adv. 2014, 4, 53674-53680. [CrossRef]

34. Zhou, L.-L.; Fang, T.; Cao, J.-P.; Zhu, Z.-H.; Su, X.-T.; Zhan, S.-Z. A dinuclear copper(II) electrocatalyst both water reduction and oxidation. J. Power Sources 2015, 273, 298-304. [CrossRef]

35. Xin, Z.-J.; Liu, S.; Li, C.-B.; Lei, Y.-J.; Xue, D.-X.; Gao, X.-W.; Wang, H.-Y. Hydrogen production in a neutral aqueous solution with a water-soluble copper complex. Int. J. Hydrog. Energy 2017, 42, 4202-4207. [CrossRef]

36. Nestke, S.; Kügler, M.; Scholz, J.; Wilken, M.; Jooss, C.; Siewert, I. A Copper Complex as Catalyst in Proton Reduction: A Copper Complex as Catalyst in Proton Reduction. Eur. J. Inorg. Chem. 2017, 2017, 3376-3382. [CrossRef]

37. Kubas, G.J.; Monzyk, B.; Crumblis, A.L. Tetrakis (Acetonitrile) Copper (1+) Hexafluorophosphate (1-). In Inorganic Syntheses; Angelici, R.J., Ed.; John Wiley \& Sons, Inc.: Hoboken, NJ, USA, 2007; pp. 68-70, ISBN 9780470132593.

38. Veroni, I.; Rontoyianni, A.; Mitsopoulou, C.A. Synthesis and characterization of a novel complex: $\mathrm{Mo}(\mathrm{CO})_{4}\left[2-\left(2^{\prime}\right.\right.$ pyridyl)quinoxaline]. An insight based on experimental and theoretical data. Dalton Trans. 2003, 255-260. [CrossRef]

39. Garoufis, A.; Perlepes, S.P.; Vreugdenhil, A.; Butler, I.S.; Hadjiliadis, N. Synthesis and characterization of 1:2 metal complexes of the biheteroaromatic ligand 2-(2'-pyridyl)quinoxaline (L) and the X-ray structure of [CuL2](PF6). Inorganica Chim. Acta. 1995, 240, 673-677. [CrossRef]

40. Martínez, N.P.; Isaacs, M.; Oliver, A.G.; Ferraudi, G.; Lappin, A.; Guerrero, J. Effects of the non-covalent interactions on the electronic and electrochemical properties of $\mathrm{Cu}(\mathrm{I})$ biquinoline complexes. Dalton Trans. 2018, 47, 13171-13179. [CrossRef]

41. Fourmond, V.; Canaguier, S.; Golly, B.; Field, M.J.; Fontecave, M.; Artero, V. A nickel-manganese catalyst as a biomimic of the active site of NiFe hydrogenases: A combined electrocatalytical and DFT mechanistic study. Energy Environ. Sci. 2011, 4, 2417. [CrossRef]

42. Fourmond, V.; Jacques, P.-A.; Fontecave, M.; Artero, V. $\mathrm{H}_{2}$ Evolution and Molecular Electrocatalysts: Determination of Overpotentials and Effect of Homoconjugation. Inorg. Chem. 2010, 49, 10338-10347. [CrossRef] [PubMed]

43. Zarkadoulas, A.; Field, M.J.; Papatriantafyllopoulou, C.; Fize, J.; Artero, V.; Mitsopoulou, C.A. Experimental and Theoretical Insight into Electrocatalytic Hydrogen Evolution with Nickel Bis(aryldithiolene) Complexes as Catalysts. Inorg. Chem. 2016, 55, 432-444. [CrossRef] [PubMed]

44. Solis, B.H.; Hammes-Schiffer, S. Proton-Coupled Electron Transfer in Molecular Electrocatalysis: Theoretical Methods and Design Principles. Inorg. Chem. 2014, 53, 6427-6443. [CrossRef] [PubMed]

45. Oxford Diffraction. CrysAlis CCD and CrysAlis RED, Version 1.171.32.15; Oxford Diffraction Ltd.: Abingdon, UK, 2008.

46. Altomare, A.; Cascarano, G.; Giacovazzo, C.; Guagliardi, A. Early finding of preferred orientation: A new method. J. Appl. Crystallogr. 1994, 27, 1045-1050. [CrossRef]

47. Sheldrick, G.M. SHELXL-97, Program for Refinement of Crystal Structures; University of Göttingen: Göttingen, Germany, 1997.

48. Farrugia, L.J. WinGX suite for small-molecule single-crystal crystallography. J. Appl. Crystallogr. 1999, $32,837$. [CrossRef] 
49. Macrae, C.F.; Bruno, I.J.; Chisholm, J.A.; Edgington, P.R.; McCabe, P.; Pidcock, E.; Rodriguez-Monge, L.; Taylor, R.; van de Streek, J.; Wood, P.A. Mercury CSD 2-New features for the visualization and investigation of crystal structures. J. Appl. Crystallogr. 2008, 41, 466-470. [CrossRef]

50. Van der Sluis, P.; Spek, A.L. BYPASS: An effective method for the refinement of crystal structures containing disordered solvent regions. Acta Crystallogr. A Found Crystallogr. 1990, 46, 194-201. [CrossRef]

51. Wu, S.; Dou, J.; Zhang, J.; Zhang, S. A simple and economical one-pot method to synthesize high-quality water soluble CdTe QDs. J. Mater. Chem. 2012, 22, 14573. [CrossRef]

52. Vosko, S.H.; Wilk, L.; Nusair, M. Accurate spin-dependent electron liquid correlation energies for local spin density calculations: A critical analysis. Can. J. Phys. 1980, 58, 1200-1211. [CrossRef]

53. Lee, C.; Yang, W.; Parr, R.G. Development of the Colle-Salvetti correlation-energy formula into a functional of the electron density. Phys. Rev. B 1988, 37, 785-789. [CrossRef]

54. Hariharan, P.C.; Pople, J.A. The influence of polarization functions on molecular orbital hydrogenation energies. Theoret. Chim. Acta 1973, 28, 213-222. [CrossRef]

55. Francl, M.M.; Pietro, W.J.; Hehre, W.J.; Binkley, J.S.; Gordon, M.S.; DeFrees, D.J.; Pople, J.A. Self-consistent molecular orbital methods. XXIII. A polarization type basis set for second row elements. J. Chem. Phys. 1982, 77, 3654-3665. [CrossRef]

56. Frisch, M.J.; Trucks, G.W.; Schlegel, H.B.; Scuseria, G.E.; Robb, M.A.; Cheeseman, J.R.; Scalmani, G.; Barone, V.; Petersson, G.A.; Nakatsjui, H.; et al. Gaussian 16; Revision C.01; Gaussian, Inc.: Wallingford, CT, USA, 2016.

57. Grimme, S.; Antony, J.; Ehrlich, S.; Krieg, H. A consistent and accurate ab initio parametrization of density functional dispersion correction (DFT-D) for the 94 elements H-Pu. J. Chem. Phys. 2010, 132, 154104. [CrossRef] [PubMed]

58. Marenich, A.V.; Cramer, C.J.; Truhlar, D.G. Universal Solvation Model Based on Solute Electron Density and on a Continuum Model of the Solvent Defined by the Bulk Dielectric Constant and Atomic Surface Tensions. J. Phys. Chem. B 2009, 113, 6378-6396. [CrossRef]

59. Namazian, M.; Lin, C.Y.; Coote, M.L. Benchmark Calculations of Absolute Reduction Potential of Ferricinium/Ferrocene Couple in Nonaqueous Solutions. J. Chem. Theory Comput. 2010, 6, 2721-2725. [CrossRef]

Publisher's Note: MDPI stays neutral with regard to jurisdictional claims in published maps and institutional affiliations.

(C) 2020 by the authors. Licensee MDPI, Basel, Switzerland. This article is an open access article distributed under the terms and conditions of the Creative Commons Attribution (CC BY) license (http://creativecommons.org/licenses/by/4.0/). 